\title{
PAULINE SCHEURLEER IN HET RIJKSMUSEUM
}

Toen Pauline in 1975 in het Rijksmuseum ging werken, bestond er nog maar enkele jaren een 'gewone' afdeling Aziatische kunst. Die afdeling was het logische vervolg op het Museum van Aziatische Kunst van de gelijknamige Vereniging van Vrienden dat sinds 1952 in het Rijksmuseum gevestigd was, aanvankelijk als een geheel zelfstandige organisatie. Maar bij de komst van Pauline was er een eigen Aziatische afdeling van het Rijksmuseum, aangezien de collectie van de Vereniging in 1972 in langdurig bruikleen was gegeven. De belangrijkste taak van de conservatoren was het bruikleen te beheren, maar het Rijksmuseum verschafte ook een eigen aankoopbudget om de verzameling in de geest van de Vereniging uit te breiden. De afdeling bleef echter uitzonderlijk, zowel door deze bijzondere geschiedenis, als door het altijd afwijkende karakter ten opzichte van de andere verzamelafdelingen in het Rijksmuseum. Wie de belangen van zo'n afdeling moet behartigen en die verantwoordelijkheid serieus neemt, heeft een 'schone' maar lang niet gemakkelijke taak. Steeds opnieuw de bijzondere positie, het grote belang en de afwijkende noden van de collectie en de afdeling toelichten aan mensen van wie Pauline soms vermoedde dat ze het nooit zouden begrijpen en wellicht niet eens wilden begrijpen - het is een aanslag op het geduld en uithoudingsvermogen geweest. Echter, het is niet zonder resultaat gebleven: collectie en afdeling zijn in 2008 vast verankerd in het Rijksmuseum, met in de toekomst een eigen paviljoen en met een collectie die door het Rijksmuseum op gezette tijden met uiterst belangrijke objecten wordt uitgebreid.

Deze stand van zaken spreekt niet voor zich. In 1975 werd Pauline assistentconservator voor Zuid- en Zuidoost-Azië. Zij was assistent van het hoofd van de afdeling Kok Wie Lim, van huis uit japanoloog, die de Oost-Aziatische collecties onder zijn hoede had. Pauline, onder leiding van professor Th.P. Galestin aan de Universiteit Leiden opgeleid in de kunstgeschiedenis en archeologie van Zuid- en Zuidoost-Azië, had zich tijdens haar studie vooral op India gericht. Aansluitend daarop catalogiseerde zij Indiase miniaturen uit de collectie Formijne voor een tentoonstelling in het Rijksprentenkabinet, maar ze begon ook op het terrein waarop zij zich later vooral zou profileren: de kunst van Indonesië. Ze was een van de organisatoren van de tentoonstelling Borobudur, Kunst en Religie van het Oude Java, in 1977.

De positie van de afdeling werd korte tijd later ter discussie gesteld. In 1981 vatte het toenmalige Ministerie van CRM het plan op de collectie over te brengen naar het Rijksmuseum voor Volkenkunde - een gedachte die in de daaropvolgende jaren op gezette tijden terugkeerde. Het was Paulines zeer uitgesproken overtuiging dat dat voorkomen moest worden en het kwam vooral op haar vastberadenheid aan, omdat haar bovengeschikte, Kok Wie Lim, het jaar daarop plotseling overleed en niet werd opgevolgd. Het moeten 
Pauline Scheurleer en H.M. Koningin Beatrix bij de opening van de Zuidvleugel, 24 april 1996. Foto Werry Crone wonderlijke jaren zijn geweest - nog betrekkelijk kort aan het werk, zonder chef of collega, met een collectie die zowel geografisch als in tijd enorm uiteenliep, en met de Vereniging die gewend was met de conservator om te gaan als haar eigen personeel, steeds in de buurt - het secretariaat was gevestigd op de kamer van de conservator. Pauline heeft zich in deze jaren met 'alles' uit de collectie beziggehouden, hetgeen tot uitdrukking kwam in artikelen en kleine presentaties op de afdeling. Niet altijd groeide daaruit een zeer warme belangstelling voor alle vormen van Aziatisch kunsthandwerk, maar wel een zeer gedegen kennis. Opvallend blijven de bruikbare adviezen die Pauline als meelezer van artikelen kan geven - ook op terreinen waarvan een ieder weet dat ze zeker níet op Paulines genegenheid kunnen rekenen. De collectie en de afdeling bleven in het Rijksmuseum, er kwam in 1985 een nieuwe conservator voor Oost-Aziatische Kunst, Klaas Ruitenbeek, (Pauline werd bij die gelegenheid hoofd) en in datzelfde jaar verscheen, onder Paulines redactionele hoede, het nieuwe handboek van de collectie: Asiatic Art in the Rijksmuseum, Amsterdam. Een boek, waaraan negen deskundigen meewerkten, dat intussen uitverkocht is, maar nog steeds gezocht is en in gebruik blijft. Het is een publicatie die in samenwerking met de Vereniging van Vrienden werd gemaakt en uitgegeven.

Onderzoek samen met Marijke Klokke naar Indonesische bronzen mondde in 1988 uit in de tentoonstelling Goddelijk brons, waarbij een bij Brill uitgegeven catalogus verscheen die geldt als standaardwerk op dit gebied. Deze resultaten betekenden niet dat de zorgen voor de toekomst voorbij waren. In diezelfde jaren (1987-1988) haalde het Ministerie in het kader van een bezuinigingsoperatie het oude plan van overplaatsing van de collectie naar Leiden weer uit de kast. Dit keer nam het Rijksmuseum maatregelen om dit gevaar te bezweren. Bij de interne reorganisatie van het Rijksmuseum in 1990 werd de afdeling één van de vijf gelijkwaardige verzamelafdelingen. In dat kader werd kort daarna het Chinese en Japanse porselein van de afdeling Beeldhouwkunst en Kunstnijverheid overgedragen aan de afdeling Aziatische Kunst. De inventarisatie van het porselein door Christiaan Jörg en Jan van Campen werd onder Paulines supervisie ter hand genomen en (al!) in 1997 verscheen de bestandscatalogus Chinese Ceramics in the Collection of the Rijksmuseum.

Maar veel zichtbaarder werd de bevestiging van de plaats van de collectie Aziatische Kunst binnen het Rijksmuseum door de verbouwing van de Drucker-uitbouw. Dit deel van het museum, vernoemd naar de verzamelaar J.C.J. Drucker en zijn echtgenote, die hun Haagse School-schilderijen en porselein aan het museum nalieten, en waar de collectie Aziatische kunst vanaf 1952 te zien was, werd nu verbouwd en omgedoopt tot Zuidvleugel. Wim Quist was de architect en Manfred Kausen de vormgever van de inrichting voor de afdeling Aziatische Kunst op de begane grond. De ontruiming en het maken van de plannen voor een nieuwe inrichting begonnen in 1993, het resultaat was in 1996 te bewonderen: de collectie vond hier zeer voordelig zijn plek.

Klaas Ruitenbeek had het museum net voor de opening verlaten om in München te gaan doceren. Zijn plaats werd in 1997 ingenomen door Menno Fitski. Op de afdeling werden in deze jaren geregeld kleine wisselende tentoonstellingen georganiseerd in een zaal die primair voor rolschilderingen bedoeld was, maar met kleine aanpassingen ook geschikt was voor driedimensionale voorwerpen. Jan van Campen, die al verschillende keren als projectmedewerker op de afdeling had gewerkt, werd in 2001 als consefvator $03 \mathrm{PM}$ 
exportkunst aangesteld, zodat er - weliswaar in deeltijd - nu drie mensen op de afdeling werkten.

Pauline publiceerde in deze periode twee belangrijke artikelen op verzamelhistorisch terrein. Over Indiase sieraden uit de collectie van stadhouder Willem $\mathrm{V}$ en over het album met Indiase miniaturen uit de collectie van Nicolaas Witsen. Naast de klassieke kunst uit Indonesië (met name goud, beeldhouwkunst in brons en steen), de kunst uit India (waaronder Indiase minaturen), is de verzamelgeschiedenis een terrein waarop Pauline belangrijke bijdragen levert. Juist door verzamelhistorische en kunsthistoriche gegevens te combineren weet zij nieuwe inzichten te verwerven. Haar vertrek uit het museum zal in dit opzicht gelukkig geen eindpunt betekenen.

Maar we lopen op de zaken vooruit. Nieuwe, grootse plannen maakten een vroegtijdig einde aan de opstelling in de Zuidvleugel. Met de bedoeling na een totale renovatie een compleet nieuwe inrichting van het museum te maken, sloot in 2003 het museum, voor wat men toen nog dacht vijf jaar. De Zuidvleugel werd Philipsvleugel en voor de periode van de verbouwing bestemd voor het tonen van de hoogtepunten van de $17^{\mathrm{e}}$-eeuwse

Rijksmuseumcollectie. Na de heropening (intussen voorzien in 2013) zullen hier tijdelijke tentoonstellingen worden gehouden. Aziatische Kunst krijgt een eigen, nieuw paviljoen.

De opstelling uit 1996, waar hard aan gewerkt was, waar veel geld aan was uitgegeven, en die extra betekenisvol was als afsluiting van een lange periode van onzekerheid over de positie van collectie en afdeling, kreeg dus een zeer voortijdig einde. Op de plaats waar zes jaar lang de Dansende Shiva in al zijn pracht de aandacht van de bezoekers voor zich opeiste, stond nu een kanon van de VOC - het was niet mogelijk de verandering beeldender gestalte te geven. Het tekent Paulines betrokkenheid en veerkracht, dat zij na een periode van afstand nemen, weer actief deelnam aan de plannen voor het nieuwe Aziatische paviljoen en aan de plannen voor het al lang verbeide nieuwe afdelingsboek. In CODA Apeldoorn werd voor de periode van drie jaar een plaats gevonden om een ruime selectie van de collectie te tonen (2004-2007), met gebruikmaking van de vitrines en sokkels die Kausen voor de Zuidvleugel ontworpen had. Organisatorisch ging de afdeling nog verder op in het museum. Bij de reorganisatie van 2006 werden de afdelingen Schilderkunst, Beeldhouwkunst/Kunstnijverheid en Aziatische Kunst samengevoegd tot één afdeling Beeldende Kunst.

Pauline heeft haar kennis overgedragen. Zij doceerde boeddhistische kunst aan de Universiteit Leiden; velen die stage liepen op de afdeling en enkele jongere collega's konden onder haar hoede het vak leren. Dat gebeurde op een doorgaans heel prettige manier. Pauline is een warm mens en buitengewoon begaan met degenen om haar heen, waarvoor zij zich met hart en ziel inzet. Die warmte gaat soms verborgen onder een strenge blik, die vooral van zich doet spreken als zij het ergens niet mee eens is. Dan gaan de ogen rollen en bliksemen haar woorden, met hart en ziel betrokken als ze is bij de zaak. De plicht goed te moeten zorgen voor de haar toevertrouwde collectie wordt door Pauline heel diep gevoeld en in de loop der jaren ontwikkelde zij een sterk besef van hoe de dingen zouden moeten zijn. Wee het gebeente van degene die dacht daar lichtvoetig tegenin te kunnen gaan! Haar strengheid bleek bijvoorbeeld uit haar visie op het verwervingsbeleid van de afdeling. De richtlijn is te verzamelen in de geest van de vereniging, 
dus alleen zeer belangrijke werken die als representant kunnen gelden van de productie in de belangrijkste centra van Azië. Daarbij hanteerde zij de Unesco-principes over de herkomst van de voorwerpen (een object dient tenminste vanaf 1970 in een Westerse collectie te zijn). In veel gevallen hebben we bij elkaar gezeten, de jongere collega's verblind door hebzucht, terwijl Pauline uitlegde dat er op dit terrein eigenlijk betere voorwerpen te vinden waren, dat het natuurlijk een enig stuk was, maar niet voor dit museum. Hoewel op die momenten misschien niet leuk, heeft dit wel geleid tot zorgvuldig gekozen belangrijke aanwinsten. Lang voordat de directie van het museum de conservatoren op het hart drukte toch vooral geen 'dingetjes' te kopen, maar uitsluitend (en heel af en toe) echt belangrijke zaken, had Pauline deze visie al in praktijk gebracht. Belangrijke verwervingen in Paulines periode in het museum op haar eigen terreinen, zijn het beeld van de drie-hoofdige Vishnu uit Kashmir, eind $8^{\mathrm{e}}$-begin $9^{\mathrm{e}}$ eeuw (AK-RAK-19903), de Noord-Indiase Durga uit de $11^{\mathrm{e}}$ eeuw (AK-RAK-1992-1) en de bronzen 'Thaise rakker', het beeld van Avalokiteshvara uit Prahkon Chai, Thailand (AK-RAK-2000-15).

Hoewel er op dit moment aanleiding is bezorgd te zijn over de serieuze bestudering van de kunsten uit Azië in Nederland - aan de universiteit is de toestand precair - is de situatie in het Rijksmuseum relatief gunstig. Pauline wordt opgevolgd door een conservator voor Zuidoost-Azië en het Indiase bedrijf Tata maakt het daarnaast mogelijk een conservator voor de kunst uit India aan te stellen. Gunstige ontwikkelingen die niet los gezien kunnen worden van wat er in de voorafgaande periode tot stand gebracht is, de periode waarin de begrippen afdeling Aziatische Kunst in het Rijksmuseum en Pauline Lunsingh Scheurleer min of meer samen vielen. 